\title{
Vulnerability and adaptation of agronomic systems in Bulgaria
}

\author{
Vesselin Alexandrov* \\ Bulgarian Academy of Sciences - N ational Institute of M eteorology and Hydrology, BG -1784 Sofia, Bulgaria
}

\begin{abstract}
Vulnerability and adaptation assessments of major agricultural crops under climate change were carried out in Bulgaria through the US Country Studies Program. Several climate change scenarios using General Circulation Model (GCM) outputs were created. Annual temperatures in the country are projected to rise between 2.9 (HCGS model) and $5.8^{\circ} \mathrm{C}$ (UK89 model) under effective doubling of $\mathrm{CO}_{2}$. Precipitation is expected to increase during the winter and to decrease during the warm half of the year. Under equilibrium $2 \times \mathrm{CO}_{2}$, the GCM climate change scenarios project an increase in the agroclimatic potential; however, warming would cause decreases in grain yield of winter wheat Triticum aestivum L. and especially maize Zea mays L. Simulated adaptation measures - such as zoning of crop production in agricultural land areas with elevation below $1000 \mathrm{~m}$, changing planting dates, altering varieties, changing optimum value and dates of fertilizer application, and irrigation - were considered as potential responses that may modify any effects of climate change on crop production in Bulgaria. An action plan in Bulgarian agriculture under climate change was developed in cooperation with the Ministry of Agriculture, Forest and Agrarian Reform. Major points of the plan are a decrease in greenhouse gas emissions (reducing methane emissions produced by biological fermentation in stock breeding and rice cultivation; decreasing methane emissions by effective utilization of manure; improving fertilization using mineral fertilizers; decreasing the carbon emissions containing gasses; and retaining soil carbon) and some adaptation measures.
\end{abstract}

KEY WORDS: Agriculture · Bulgaria · Climate change · DSSAT · GCMs · M aize · Winter wheat · Yield

\section{INTRODUCTION}

There is no doubt the question of global climate change is a major and important environmental issue facing the world at the end of the 20th century. Potential climate change will probably have significant impact on the world economy during the next $100 \mathrm{yr}$. That is why the United Nations Framework Convention on Climate Change, which has been signed by more than 150 governments worldwide, calls on parties to the Convention to inventory national sources and sinks of greenhouse gasses and to develop plans for responding to climate change. To assist developing countries and countries with economies in transition to meet this obligation, the US Country Studies Program

*E-mail: vesselin.alexandrov@meteo.bg was created to support climate change country studies through technical and financial assistance. Bulgaria, which signed the Convention in J une 1992 and ratified it in March 1995, was also involved in the program. The Bulgarian country study was initiated in 1994. An action plan under expected climate change during the next century in the country was developed.

Global climate change will influence all economic sectors to some degree, but agricultural production is perhaps the most sensitive and vulnerable. Recent research has focused on farm-level, regional, national, and global assessments of the potential impacts of climate change on agriculture (Kaiser \& Drennen 1993, Rosenzweig \& Parry 1994, Wei et al. 1994, Harrison et al. 1995, Rosenzweig \& Hill 1995, Rosenzweig et al. 1995, Peiris et al. 1996, Smith et al. 1996, Watson et al . 1996, Brown \& Rosenberg 1997, IPCC 1997). Studies on the effect of expected changes in climate on agricultural production in Bulgaria were also initiated 
(Raev et al. 1996, Republic of Bulgaria 1996, Alexandrov 1997d, 1998, Slavov \& Alexandrov 1997). The major objective of this paper is to present some national vulnerability and adaptation assessments of important agricultural systems (maize and winter wheat) and some features of the action plan for Bulgarian agriculture.

\section{MATERIAL AND METHODS}

2.1. G eographic location. Bulgaria is situated on the Balkan peninsula in southeast Europe. Lowlands ( 0 to $200 \mathrm{~m}$ ) cover $31.45 \%$ of the country, hills ( 200 to $600 \mathrm{~m}$ ) $40.90 \%$, highlands ( 600 to $1600 \mathrm{~m}$ ) $25.13 \%$, and mountains over $1600 \mathrm{~m} 2.52 \%$. The country is split into North and South Bulgaria by the Balkan Mountains, which have a strong effect on the temperature regime. The zonal situation of the Balkan M ountains increases the climatic differences between North and South Bulgaria, arising as a result of the atmospheric circulation. The country belongs to the mild climate zone, with a typical rotation of 4 seasons and variable weather throughout the year. The climate is continental in the north and close to Mediterranean in the south. The annual mean temperature in Bulgaria varies from -3.0 to $14.0^{\circ} \mathrm{C}$. The simple annual course of air temperature has a minimum in J anuary and a maximum in J uly. The monthly mean temperatures in J anuary and J uly are in the range -10.9 to $3.2^{\circ} \mathrm{C}$ and 5.0 to $25.0^{\circ} \mathrm{C}$, respectively. Precipitation amounts depend crucially on circulation patterns, site elevation, and site-specific orographic features. The annual amount of precipita-

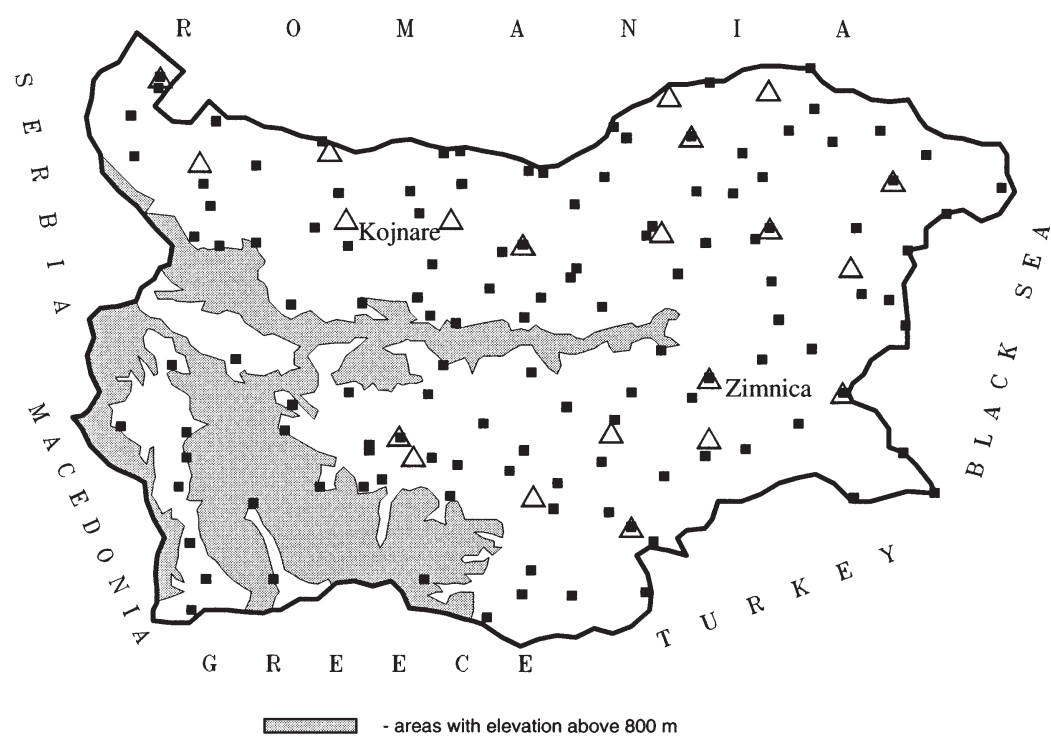

Fig. 1. Distribution of the experimental variety $(\Delta)$ and meteorological $(\square)$ stations in Bulgaria with elevation below $800 \mathrm{~m}$ tion is between 500 and $650 \mathrm{~mm}$, with precipitation ranging from 440 to $1020 \mathrm{~mm}$. The highest monthly values are measured in J une (at some places in May), with mean totals between 55 and $85 \mathrm{~mm}$. February (or $\mathrm{M}$ arch) is the driest month, with mean totals between 30 and $45 \mathrm{~mm}$ (Koleva 1993). Although precipitation in Bulgaria is significant throughout the year, precipitation during the warm months, April through September, is most important, especially for agriculture. The average national precipitation during this time of the year is $333 \mathrm{~mm}$, and the standard deviation is $72 \mathrm{~mm}$. Maximum precipitation is $573 \mathrm{~mm}$ (for the Balkan Mountains), and minimum precipitation is $211 \mathrm{~mm}$ (Alexandrov 1993).

2.2. Experimental material. 2.2.1. Data collection: Twenty-one experimental crop variety stations in Bulgaria with elevation below $800 \mathrm{~m}$ were selected for the simulation study (Fig. 1). This is because the greatest part of the national crop (mainly winter wheat and maize) production is concentrated in areas with elevation below $800 \mathrm{~m}$. Besides, most General Circulation Models (GCMS) assume smoothed orographic features. Meteorological and agrometeorological data from the stations were gathered from 1980 to 1995. To obtain the spatial distribution of the potential crop growing season and accumulated temperatures under the expected climate, 125 meteorological stations were also selected for the simulation study (Fig. 1). The $30 \mathrm{yr}$ baseline climate data used in this study were from the period 1961-1990, as recommended by the World M eteorological Organization (WMO). Mainly, monthly data of air temperature and precipitation from these stations were used.

2.2.2. Climate change scenarios: Seven GCMs were used to simulate the effect of doubled $\mathrm{CO}_{2}$ on the observed data from the current climate (19611990). The GCMs that were used are those from the Goddard Institute for Space Studies (GISS), Geophysical Fluid Dynamics Laboratory (GFDL R-30 and GFDL-T), Canadian Climatic Centre $(C C C)$, Oregon State University (OSU), United Kingdom M eteorological Office (UK89), and Hadley Centre (HCGG and HCGS, which integrates the negative forcing effect from sulfate aerosols). The GCM outputs were provided by the US Country Studies Program $M$ anagement Team.

The single levels of $\mathrm{CO}_{2}\left(1 \times \mathrm{CO}_{2}\right)$ outputs from the GCMs were compared with averaged baseline climate data. The $1 \times \mathrm{CO}_{2}$ OSU, HCGG, and HCGS outputs could be considered as the most 

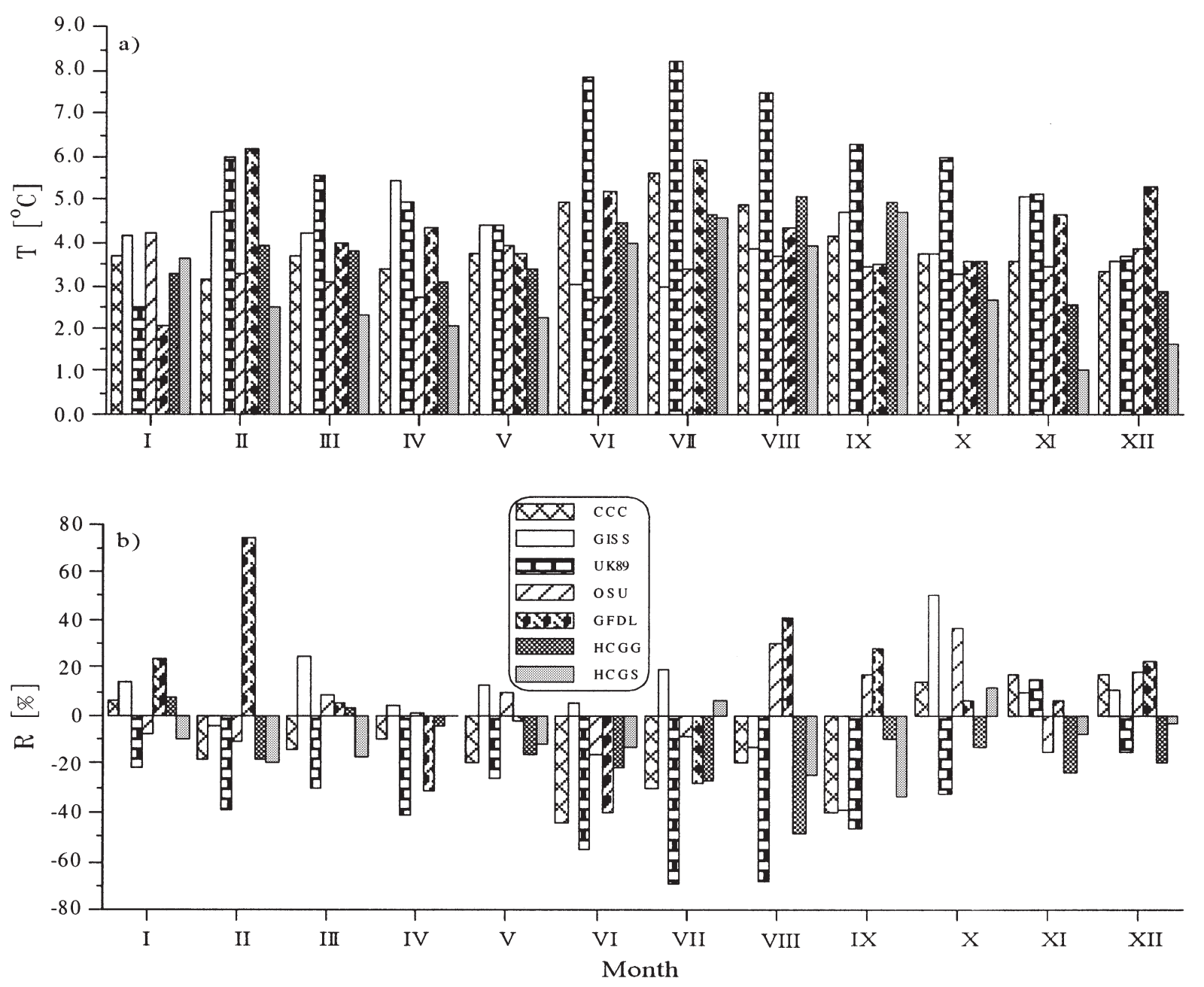

Fig. 2. Differences or ratios between $2 \times \mathrm{CO}_{2}$ and $1 \times \mathrm{CO}_{2} \mathrm{GCM}$ outputs for (a) monthly air temperature and (b) precipitation in Bulgaria

appropriate models for monthly air temperature in Bulgaria (except A pril and $\mathrm{M}$ ay) among the GCM s used in the study. The $1 \times \mathrm{CO}_{2} \mathrm{CCC}$ and GFDL R-30 models simulate relatively well current precipitation throughout the period from November to A pril. According to the GCM s used in the study, annual temperatures in Bulgaria are predicted to rise between 2.9 (HCGS) and $5.8^{\circ} \mathrm{C}$ (UK89) under an effective doubling of $\mathrm{CO}_{2}$ $\left(2 \times \mathrm{CO}_{2}\right)$. Under the GFDL-T transient scenario in the 2000s, 2030s, and 2060s, annual temperatures are projected to increase by $1.2,2.2$, and $3.9^{\circ} \mathrm{C}$, respectively. In general, precipitation is expected to increase during the winter and to decrease during the warm half of the year (CCC, GISS, GFDL R-30, GFDL-T, OSU). The $2 \times$ $\mathrm{CO}_{2}$ UK89 and HCGS models project minor increases only in November and J uly, respectively (Figs. $2 \& 3$ ) (Alexandrov 1997a, 1998).

2.3. Methods. 2.3.1. Decision Support System for Agrotechnology Transfer (DSSAT V3.0): The Interna- tional Benchmark Sites Network for Agrotechnology Transfer (IBSNAT) Project has developed a computerized DSSAT which integrates soil, weather, and crop databases with dynamic crop simulation models (IBSNAT 1990, 1991, 1993, Tsuji et al. 1994). System analysis and validated crop simulation models provide an alternative method for representing crop production. Using models, crop growth and development can be readily evaluated under a wide range of management and environmental conditions. One of the most helpful applications of this program is in evaluating strategies for addressing climate change impacts on agricultural crops and agrotechnological management.

The DSSAT CERES GENERIC 3.0 models for maize and wheat were calibrated and verified at the experimental variety stations used in the study. Winter wheat Triticum aestivum $L$. was grown under rainfed conditions and maize Zea mays L. was irrigated at 9 experimental stations during the periods of calibration 

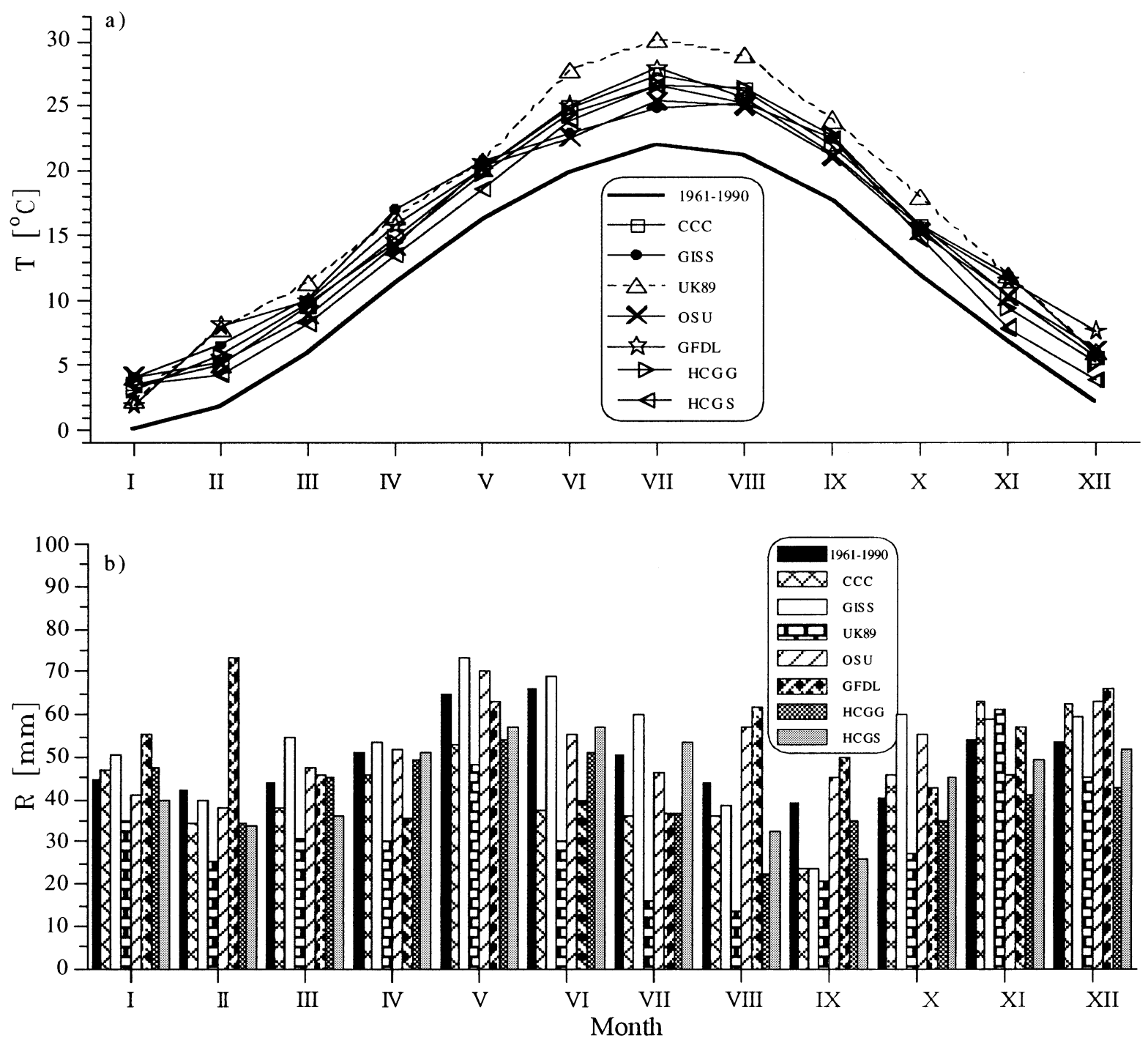

Fig. 3. Current climate (1961-1990) and $2 \times \mathrm{CO}_{2} \mathrm{GCM}$ climate change scenarios for (a) monthly air temperature and (b) precipitation in areas with elevation below $800 \mathrm{~m}$ in Bulgaria

(1980-1990) and verification (1981-1995). Different soil types (for example, typical chernozems; leached chernozem-smolnitza; grey forest, moderately loamy; leached cinnamonic forest; delluvial-meadow, sandy; alluvial, clayey-sandy; and so forth) were used. The major fertilizers incorporated were nitrogen, phosphorus, and potassium. The Bulgarian maize hybrid 'Knezha 611' and wheat variety 'Sadovo 1' were planted every year of the investigation. Simulated phenological stages and grain yields of maize and winter wheat were generally in accord with the measured data (Slavov et al. 1996, Alexandrov 1997b,c).

2.3.2. Determination of potential crop growing season and accumulated temperatures: A method suggested by Fedorov (Gulinova 1974) was used to simulate the beginning, end, and duration of the potential crop growing season as well as the accumulated temperature sums above a base of 5 and $10^{\circ} \mathrm{C}$. Where daily data were missing, a BGMETEO weather generator was also used (Alexandrov \& Valkov 1993).

\section{LIMITATIONS}

A major limitation of using GCMs is that, although they accurately represent global climate, their estimates of current regional climate are often inaccurate. A single GCM or even several GCMs may not represent the range of potential climate change in a region. All GCMs are of global scale with smoothed orographic features and low resolution. The range of values of results from GCM studies is 1.9 to $5.2^{\circ} \mathrm{C}$. Most 
results are close to $4^{\circ} \mathrm{C}$. However, according to the last IPCC contributions for the mid-range IPCC emission scenario, assuming the 'best estimate' value of climate sensitivity and including the effects of future increases in aerosol, models project an increase in global mean surface air temperature relative to 1990 of about $2^{\circ} \mathrm{C}$ by 2100 (Houghton et al. 1996). The GCM climate change scenarios also do not include changes in climate variability that might represent a very important factor for crop production.

The CERES GENERIC 3.0 crop models embody a number of simplifications. For example, there are no extreme weather events, such as hailstorms and dry winds. The models were calibrated and validated to experimental field data, which may have yields that are not typical of current farming conditions. Technology and land use were assumed to be constant, even though it is certain that they will change in the future. Thus the effects of climatic change on yields in farmers' fields may be different from those simulated by the crop models.

\section{RESULTS AND DISC USSION}

\subsection{Vulnerability assessments}

The climate change scenarios derived for Bulgaria were used to evaluate potential changes in growing season, phenological development, and yield of the major cereal crops in the country-maize and winter wheat.

Under equilibrium $2 \times \mathrm{CO}_{2}$, the potential growing season above a base of 5 and $10^{\circ} \mathrm{C}$ occurred mainly $3 \mathrm{wk}$ to 1 mo earlier than the averages under the current climate. The end of the growing season also occurred later due to warming - the deviations were between 20 and $40 \mathrm{~d}$. That is why the climate change scenarios projected an increase in the duration of the potential crop growing season by 1 to 2.5 mo. Some northward shift of productive potential was evident; in addition, the accumulated temperature increased (Fig. 4).

The altered temperature and precipitation databases corresponding to each of the climate change scenarios were used to run the CERES GENERIC 3.0 simulation models for maize and winter wheat. Crop management, technology, and distribution of cultivated land were assumed to be constant.

Agricultural production is very sensitive to change and variation in weather conditions during the regular growing season. All the developmental processes, starting as early as the germination process immediately after planting, and as late as the ripening process during physiological maturity, are affected and con-
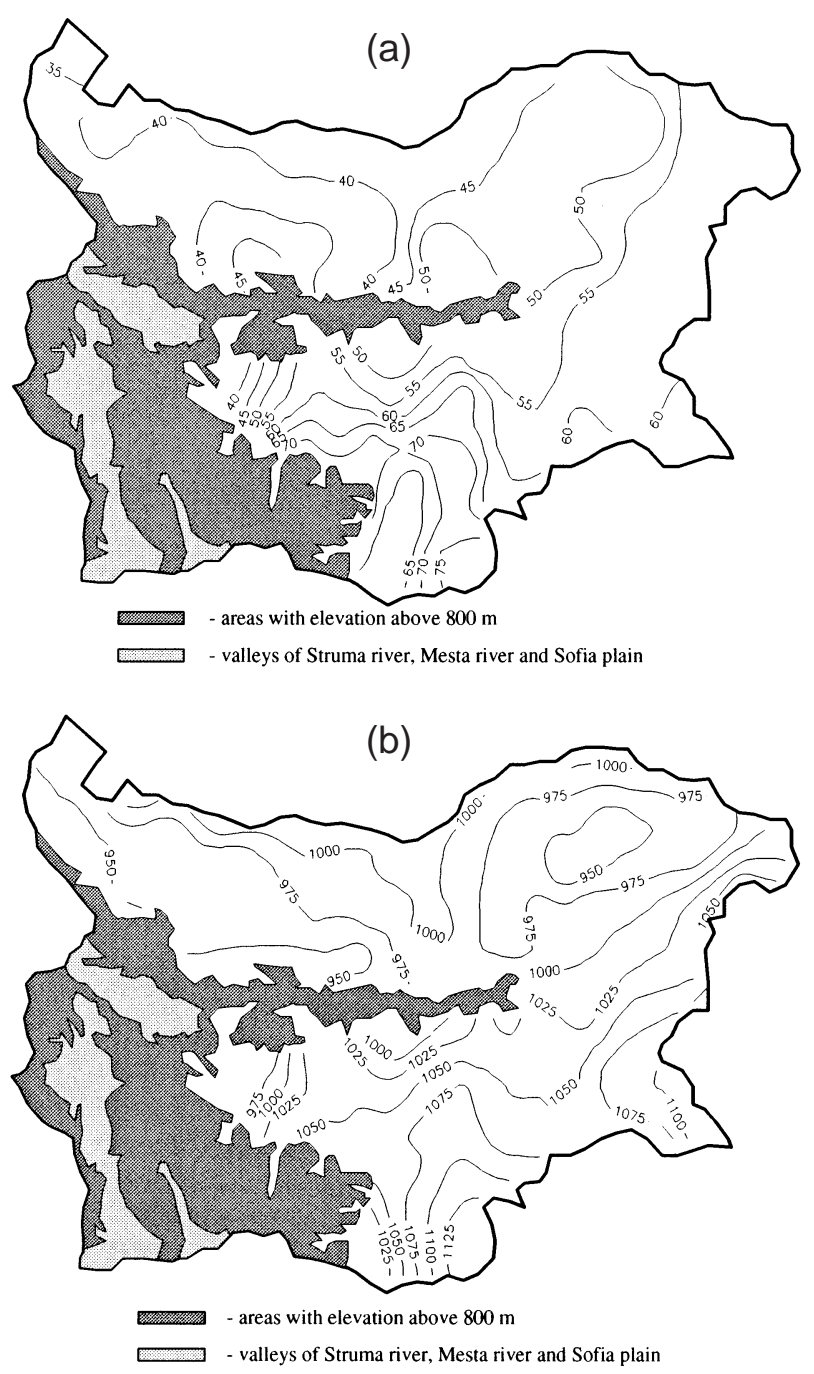

Fig. 4. Departures of (a) the duration of growing season (in days) and (b) the accumulated temperatures (in ${ }^{\circ} \mathrm{C}$ ) above a base of $10^{\circ} \mathrm{C}$ under $2 \times \mathrm{CO}_{2} \mathrm{GFDL}$ R-30, relative to the current climate

trolled by temperature. All scenarios projected shorter vegetative (sowing to silking/anthesis) and reproductive (silking/anthesis to full maturity) growing seasons of maize and wheat (Fig. 5). These changes were driven by the temperature increases of the scenarios.

Simulated decreases in maize grain yield in Bulgaria were caused primarily by warming and precipitation deficit during the growing season of this crop. Maize grain yield was more vulnerable under the CCC, GFDL, and (especially) UK89 scenarios: yield reductions were near $30 \%$ for the first two and 50 to $60 \%$ for the latter. Under the GISS, OSU, and HCGS scenarios, losses were projected to be below $20 \%$ (Fig. 6). In comparison with the other GCM outputs for Bulgaria, the $2 \times \mathrm{CO}_{2}$ GISS scenario did not have as great of a negative effect on yields. This is because the GISS model simulated in- 

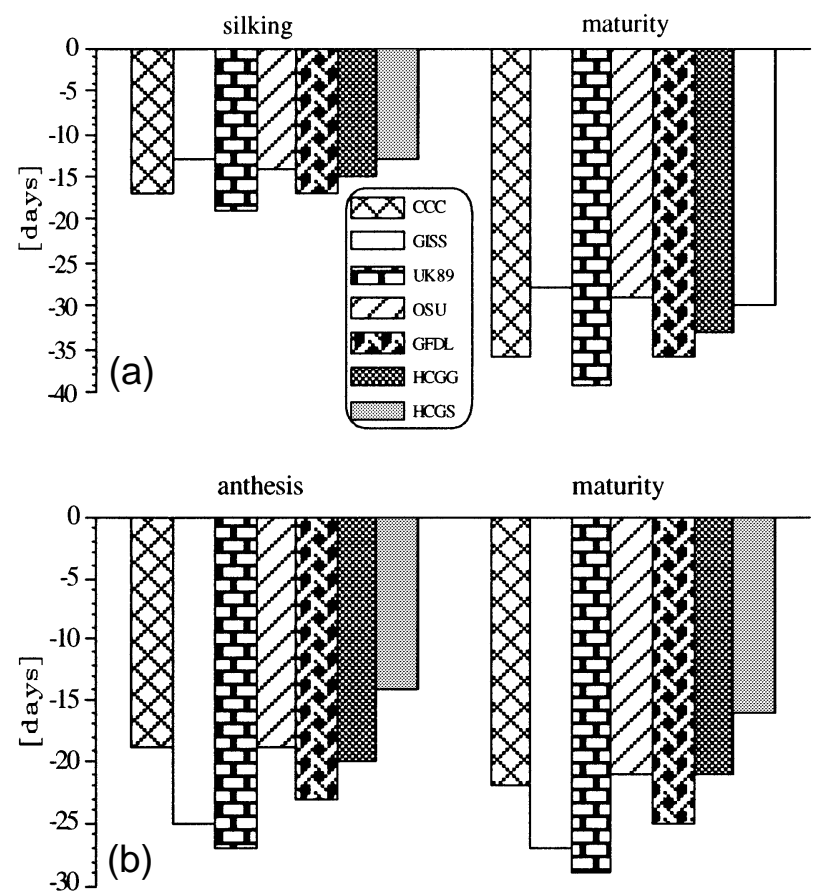

Fig. 5. Departures of phenological stages of (a) maize and (b) winter wheat under $2 \times \mathrm{CO}_{2} \mathrm{GCM}$ scenarios, relative to the current climate at 2 experimental crop stations-(a) Kojnare and (b) Zinmica. Negative values: phenological stages occurred earlier, relative to the current climate sented trends-maize yield decreased, and winter wheat yield increased (Fig. 7).

The most vulnerable agricultural crops under climate change are expected to be: (1) spring crops due to the projected precipitation reduction during the warm half of the year; (2) crops cultivated on light soils; (3) non-irrigated crops; and (4) crops in southeastern Bulgaria where a summer precipitation deficit is observed even in the current climate.

\subsection{A daptation assessments}

It is important for nations participating in the US Country Studies Program to assess options for adapting to climate change because it is unlikely that climate change can be completely averted. Although measures are being taken to reduce greenhouse gas emissions, and these measures will probably reduce the rate and magnitude of climate change, it is unlikely that greenhouse gas emissions can be reduced enough to stabilize climate; therefore, adaptation will be necessary. The goals of agricultural adaptation measures are to promote sustainable development and to minimize the impact of climate change by reducing vulnerability to its effects. Adaptation to a changing climate will occur in several forms, including, for example, technical innovations, changes in agricultural land areas, and changes in use of irrigation. creases of rainfall during the vegetative period of maize. The GISS, OSU, and HCGS scenarios also had the lowest warming in this part of the year. All climate change scenarios produced average winter wheat yield changes between -5 and $-20 \%$, although the $2 \times$ $\mathrm{CO}_{2}$ GISS, OSU, and GFDL outputs showed increases of precipitation from October to $M$ arch.

Some changes were observed when the direct effect of increased $\mathrm{CO}_{2}$ was assumed in the study. In this case, the reduction of maize grain yield decreased and winter wheat yield increased relative to the current climate. The reason for these changed results was the influence of increased levels of $\mathrm{CO}_{2}$ acting as a fertilizer.

The GFDL-T transient scenarios were used to assess the effect of gradual changes in climate for the decades of the 2000s, 2030s, and 2060s on maize and winter wheat yields under different $\mathrm{CO}_{2}$ levels. The yield trends obtained are similar to the above-pre-
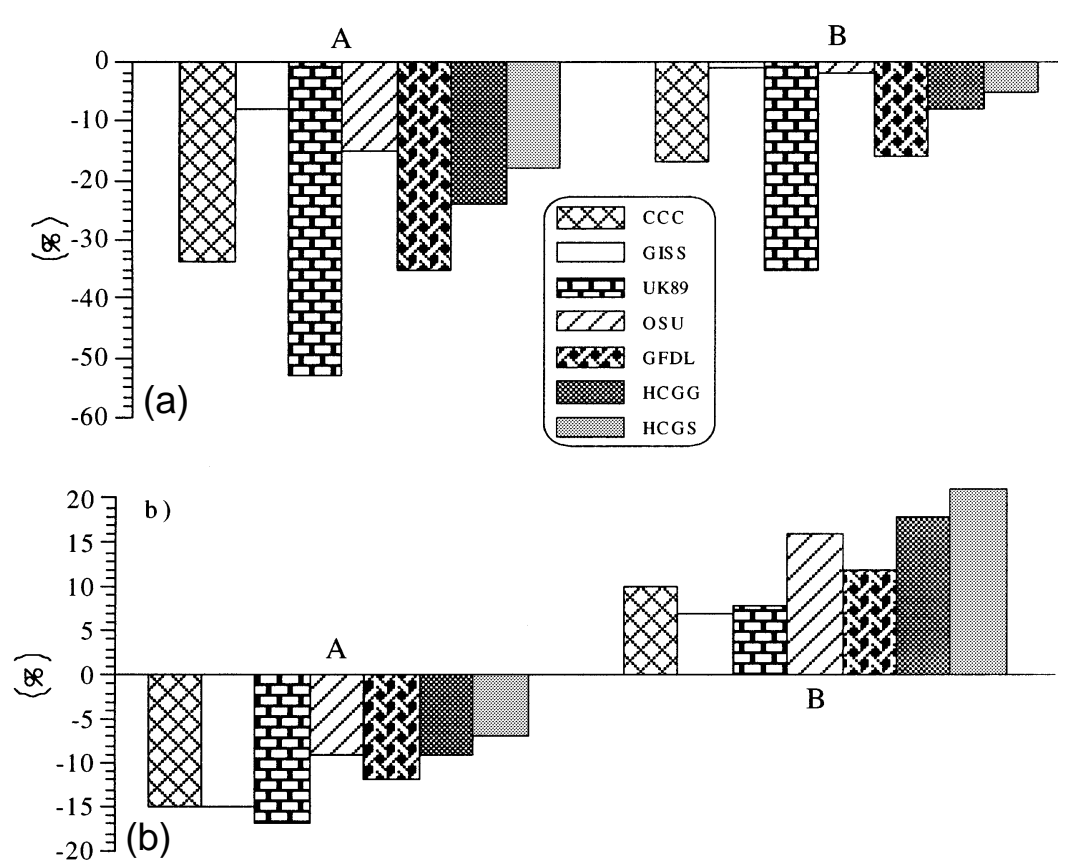

Fig. 6. Departures of grain yield of (a) maize and (b) winter wheat under $2 \times \mathrm{CO}_{2}$ scenarios, relative to the current climate at 2 experimental crop stations(a) Kojnare and (b) Zinmica. A, B: without/with direct influence of $\mathrm{CO}_{2}$ on maize and winter wheat 
The possible adaptation measures in agriculture considered in Bulgaria are given in the following sections.

\subsubsection{Zoning crop production in agricultural land areas with elevation below $1000 \mathrm{~m}$}

The greatest part of the national wheat and maize production under the current climate is concentrated in areas with elevation below $800 \mathrm{~m}$. New zoning of cereal crop production in agricultural land areas with elevation below $1000 \mathrm{~m}$ due to expected warming was proposed by N. Slavov (Raev et al. 1996, Slavov \& Alexandrov 1997). In this case, the agricultural land area for cultivation of cereal crops would increase by approximately 50000 ha.

\subsubsection{Change in crops}

Crop diversification allows farmers to cope with climate variation from year to year. This type of adaptation will likely occur at the farm system level. Switching from monocultures, which are more vulnerable to climate change, pests, and diseases, to more diversified agricultural production systems will also help farmers to cope with changing climatic conditions. Seed banks that maintain a variety of seed types provide an opportunity for farmers to diversify to counter the threat of climate change or to develop a profitable specialization. Farmers may also switch to different crop types or change to more drought- and disease-tolerant crops. Development of more and better heat- and drought-resistant crops will help to fulfill current and future food demand. Another farm-level adaptation strategy is to alter the crop mix in response to a change in climate. If climate change affects the relative yield and profitability of one crop in favor of another, then farmers should respond by making the appropriate change in crop mix.

The expected thermal and humid conditions in Bulgaria will permit farmers to vary the assortment of many fruit and vegetable crops. Grape and fig production is expected to increase in future. The climate in South Bulgaria is influenced by the M editerranean. Warming may cause a natural northward shift of some agricultural crops and trees grown in the upper areas of neighboring countries such as Greece, Turkey, and so forth.

\subsubsection{Change in sowing dates}

Under the $2 \times \mathrm{CO}_{2}$ climate change scenarios, the sowing dates would shift in order to reduce the yield loss from the warming. Using the DSSAT V3.0 software, numerical experiments under altered sowing dates of maize and winter wheat were done. Under the $2 \times \mathrm{CO}_{2}$ climate change scenarios, the sowing dates of maize should occur 15 to $30 \mathrm{~d}$ earlier, relative to those under the current climatic conditions (Table 1). Initially, sowing dates of winter wheat were moved forward to winter because climate scenarios suggest that the autumn climate would be warmer than it is under the current climate. However, that change in planting dates was the reason for a bigger decrease of grain yield of winter wheat (when the direct effect of $\mathrm{CO}_{2}$ was not assumed). Higher air temperatures during the reproductive period negatively affect wheat yield even under the current climate conditions in the country. That is why the sowing dates of wheat were moved back to the end of summer. The results obtained were better; however, it could be difficult for cultivation of second crops after harvesting the previous winter crops. Generally, the changes in sowing dates of maize and winter wheat did not compensate significantly for the decreases of grain yield.
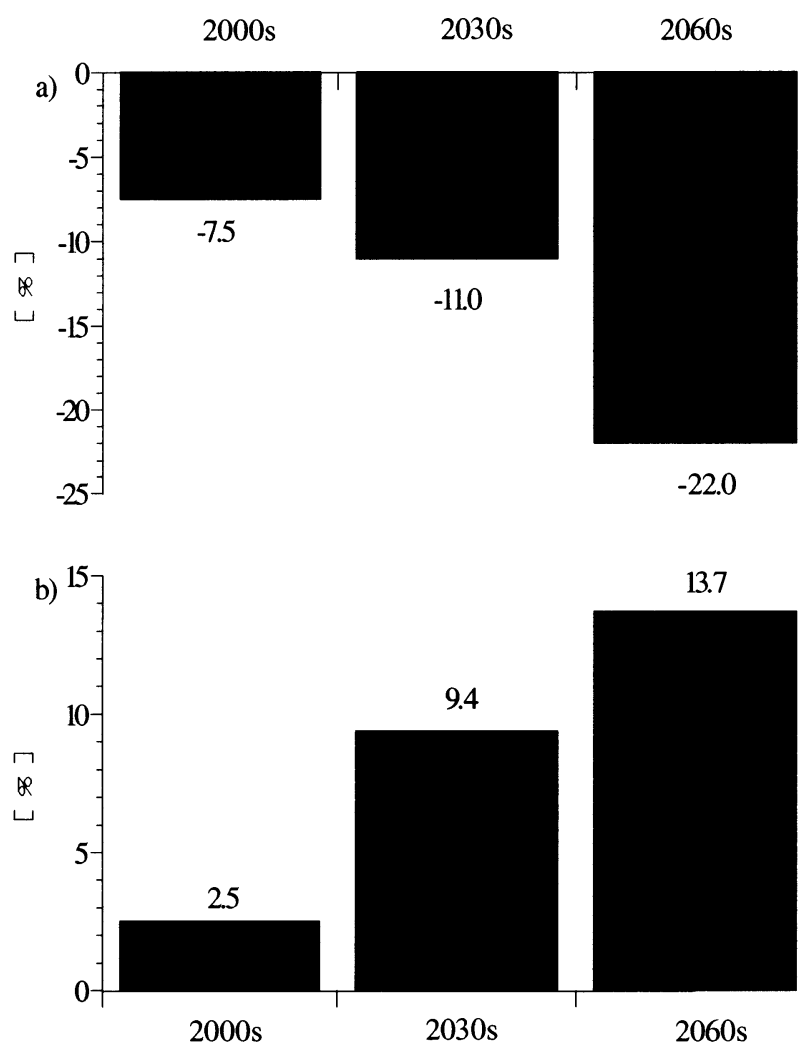

Fig. 7. Departures of grain yield stages of (a) maize and (b) winter wheat under the GFDL-T transient scenario, relative to the current climate at 2 experimental crop stations(a) Kojnare and (b) Zimnica. 2000s: $\mathrm{CO}_{2}=330$ ppmv; 2030s: $\mathrm{CO}_{2}=440$ ppmv; 2060s: $\mathrm{CO}_{2}=515$ ppmv 
Table 1. Departures of phenological stages, grain yield of maize (hybrid group 600), net return and efficiency under changes in planting date, relative to the current climate ( $1 \mathrm{May}$ ), under $2 \times \mathrm{CO}_{2} \mathrm{GCM}$ climate change scenarios at Kojnare. $\mathrm{A}$, B: without/ with direct effect of $\mathrm{CO}_{2}$. I, II, III, IV: efficiency grade, I being best

\begin{tabular}{|c|c|c|c|c|c|c|}
\hline GCM & $\begin{array}{l}\text { Sowing } \\
\text { date }\end{array}$ & $\begin{array}{l}\text { Silking } \\
\text { (d) }\end{array}$ & $\begin{array}{l}\text { Full maturity } \\
\text { (d) }\end{array}$ & $\begin{array}{c}\text { Grain yield } \\
(\%)\end{array}$ & $\begin{array}{l}\text { Net return } \\
(\%)\end{array}$ & Efficiency \\
\hline $\mathrm{CCC} A$ & $\begin{array}{l}01 \mathrm{Mar} \\
15 \mathrm{Mar} \\
01 \mathrm{Apr} \\
15 \mathrm{Apr}\end{array}$ & $\begin{array}{l}-39 \\
-37 \\
-30 \\
-23\end{array}$ & $\begin{array}{l}-56 \\
-54 \\
-49 \\
-42\end{array}$ & $\begin{array}{l}-29.6 \\
-27.2 \\
-28.5 \\
-27.8\end{array}$ & $\begin{array}{l}-37.1 \\
-33.8 \\
-35.3 \\
-34.2\end{array}$ & $\begin{array}{l}\text { IV } \\
\text { I } \\
\text { III } \\
\text { II }\end{array}$ \\
\hline CCC B & $\begin{array}{l}01 \mathrm{Mar} \\
15 \mathrm{Mar} \\
01 \mathrm{Apr} \\
15 \mathrm{Apr}\end{array}$ & $\begin{array}{l}-39 \\
-37 \\
-30 \\
-23\end{array}$ & $\begin{array}{l}-56 \\
-54 \\
-49 \\
-42\end{array}$ & $\begin{array}{l}-23.1 \\
-21.8 \\
-23.5 \\
-22.4\end{array}$ & $\begin{array}{l}-28.8 \\
-27.0 \\
-29.0 \\
-27.5\end{array}$ & $\begin{array}{l}\text { III } \\
\text { I } \\
\text { IV } \\
\text { II }\end{array}$ \\
\hline GISS A & $\begin{array}{l}01 \mathrm{Mar} \\
15 \mathrm{Mar} \\
01 \mathrm{Apr} \\
15 \mathrm{Apr}\end{array}$ & $\begin{array}{l}-45 \\
-42 \\
-34 \\
-24\end{array}$ & $\begin{array}{l}-55 \\
-53 \\
-46 \\
-38\end{array}$ & $\begin{array}{l}-18.2 \\
-17.2 \\
-17.3 \\
-14.7\end{array}$ & $\begin{array}{l}-22.9 \\
-21.6 \\
-21.4 \\
-18.1\end{array}$ & $\begin{array}{l}\text { IV } \\
\text { III } \\
\text { II } \\
\text { I }\end{array}$ \\
\hline GISS B & $\begin{array}{l}01 \mathrm{Mar} \\
15 \mathrm{Mar} \\
01 \mathrm{Apr} \\
15 \mathrm{Apr}\end{array}$ & $\begin{array}{l}-45 \\
-42 \\
-34 \\
-24\end{array}$ & $\begin{array}{l}-55 \\
-53 \\
-46 \\
-38\end{array}$ & $\begin{array}{l}-13.1 \\
-12.5 \\
-12.8 \\
-9.9\end{array}$ & $\begin{array}{l}-16.5 \\
-15.7 \\
-15.7 \\
-12.1\end{array}$ & $\begin{array}{l}\text { IV } \\
\text { II } \\
\text { II } \\
\text { I }\end{array}$ \\
\hline GFDL A & $\begin{array}{l}01 \mathrm{Mar} \\
15 \mathrm{Mar} \\
01 \mathrm{Apr} \\
15 \mathrm{Apr}\end{array}$ & $\begin{array}{l}-41 \\
-39 \\
-33 \\
-25\end{array}$ & $\begin{array}{l}-58 \\
-56 \\
-51 \\
-44\end{array}$ & $\begin{array}{l}-29.6 \\
-27.4 \\
-27.4 \\
-28.5\end{array}$ & $\begin{array}{l}-37.2 \\
-34.3 \\
-33.9 \\
-35.4\end{array}$ & $\begin{array}{c}\text { IV } \\
\text { I } \\
\text { II } \\
\text { III }\end{array}$ \\
\hline GFDL B & $\begin{array}{l}01 \mathrm{Mar} \\
15 \mathrm{Mar} \\
01 \mathrm{Apr} \\
15 \mathrm{Apr}\end{array}$ & $\begin{array}{l}-16 \\
-41 \\
-39 \\
-33\end{array}$ & $\begin{array}{l}-58 \\
-56 \\
-51 \\
-44\end{array}$ & $\begin{array}{l}-23.4 \\
-22.3 \\
-22.7 \\
-23.2\end{array}$ & $\begin{array}{l}-29.1 \\
-27.7 \\
-28.1 \\
-28.7\end{array}$ & $\begin{array}{c}\text { IV } \\
\text { I } \\
\text { II } \\
\text { III }\end{array}$ \\
\hline GFDL 2000s & $\begin{array}{l}01 \mathrm{Mar} \\
15 \mathrm{Mar} \\
01 \mathrm{Apr} \\
15 \mathrm{Apr}\end{array}$ & $\begin{array}{l}-24 \\
-23 \\
-17 \\
-11\end{array}$ & $\begin{array}{l}-31 \\
-29 \\
-24 \\
-18\end{array}$ & $\begin{array}{l}-12.5 \\
-10.0 \\
-9.3 \\
-9.4\end{array}$ & $\begin{array}{l}-15.9 \\
-12.9 \\
-11.6 \\
-11.7\end{array}$ & $\begin{array}{c}\text { IV } \\
\text { III } \\
\text { I } \\
\text { II }\end{array}$ \\
\hline GFDL 2030s & $\begin{array}{l}01 \mathrm{Mar} \\
15 \mathrm{Mar} \\
01 \mathrm{Apr} \\
15 \mathrm{Apr}\end{array}$ & $\begin{array}{l}-27 \\
-26 \\
-20 \\
-15\end{array}$ & $\begin{array}{l}-39 \\
-38 \\
-32 \\
-28\end{array}$ & $\begin{array}{l}-14.3 \\
-14.3 \\
-11.0 \\
-11.8\end{array}$ & $\begin{array}{l}-18.2 \\
-18.0 \\
-13.9 \\
-14.5\end{array}$ & $\begin{array}{l}\text { IV } \\
\text { III } \\
\text { I } \\
\text { II }\end{array}$ \\
\hline GFDL 2060s & $\begin{array}{l}01 \mathrm{Mar} \\
15 \mathrm{Mar} \\
01 \mathrm{Apr} \\
15 \mathrm{Apr}\end{array}$ & $\begin{array}{l}-37 \\
-35 \\
-28 \\
-22\end{array}$ & $\begin{array}{l}-53 \\
-51 \\
-46 \\
-40\end{array}$ & $\begin{array}{l}-21.4 \\
-21.2 \\
-20.9 \\
-19.8\end{array}$ & $\begin{array}{l}-26.7 \\
-26.5 \\
-26.1 \\
-24.5\end{array}$ & $\begin{array}{l}\text { IV } \\
\text { III } \\
\text { II } \\
\text { I }\end{array}$ \\
\hline
\end{tabular}

\subsubsection{Change in fertilization}

Changes in climate might have large effects on soils. In the light of this, land use policy may need to be reviewed with regard to the changing potential of soils for crops. In this option, the optimum amount of fertilizers and the optimum soil depth of nitrogen insertion could be examined.

An attempt to examine the optimum amount of fertilizers for maize and winter wheat development, growth, and yield formation was made. There were no changes in maize grain yield under either an increase or a decrease of nitrogen fertilizer by $100 \mathrm{~kg} \mathrm{ha}^{-1}$. The main reason for these results was the water stress that could be observed under warming during the summer season of the next century. Moreover, increased amounts of fertilizer led to a decrease in the net return calculated by the DSSAT seasonal analysis program. It was already mentioned that increased precipitation is expected under a warmer climate during winter wheat vegetation. That is why a reduction of wheat grain yield losses due to changed fertilization was obtained. As a result, net return was reduced when a higher amount of fertilizers was applied. Generally, the changes in fertilization that were tested also slightly compensated for the decrease in maize and winter wheat yield under the $2 \times \mathrm{CO}_{2} \mathrm{GCM}$ climate change scenarios. 


\subsubsection{Change in irrigation}

As the climate warms, there will likely be shifts toward greater use of irrigation systems to grow crops in Bulgaria. Even under the current climate, the available soil moisture is insufficient for spring crop cultivation in the country for normal crop growth. M any farming technologies, such as efficient irrigation systems, provide opportunities to reduce direct dependence on natural factors such as precipitation and runoff. Improvements allow greater flexibility by reducing water consumption without reducing crop yields. The use of more efficient irrigation systems can be expected because of the need for tighter water management practices to counter increased demand. For orchards and vines, drip-irrigation systems can be used to conserve water. Water losses through seepage and evaporation in canal and flood irrigation systems can be minimized by lining the canals with cement or switching to pipe irrigation systems. The significantly higher costs of production related to irrigation systems will most likely result in shifts to less water-demanding uses in areas where there are higher rates of moisture loss. Using more groundwater for crop irrigation is also a prospective method. First of all, however, the irrigation systems available until the 1990s should be restored in the country.

The DSSAT seasonal analysis program was run to determine the most appropriate timing and water amount of irrigation applications under the expected climate change during the growing season of maize. Both biophysical and economic analyses were done. The strategic analysis was done in respect to the simulated value of harvest maize yield and net return. The tested treatments of the irrigated numerical experiment assumed maize growth and development under rain-fed conditions, different dates, and different amounts of irrigated water (Table 2). In the first case (harvest yield of maize), Treatment 6 , which involved the application of $80 \mathrm{~mm}$ of water on 3 different dates, could be considered as the most appropriate irrigation

Table 2. Description of the irrigation treatments examined at Kojnare under the $\mathrm{CCC} 2 \times \mathrm{CO}_{2}$ climate change scenario

\begin{tabular}{|llc|}
\hline Treatment & Dates of irrigation & $\begin{array}{c}\text { Water applied } \\
(\mathrm{mm})\end{array}$ \\
\hline 1 & Rain-fed & - \\
2 & 8 Aug & 40 \\
3 & 29 J un & 40 \\
4 & 29 J un, 24 J ul & 80 \\
5 & 29 J un, 14 Jul, 8 Aug & 120 \\
6 & 29 J un, 14 J ul, 8 Aug & 240 \\
\hline
\end{tabular}

strategy (Fig. 8). In the second case, the economic analysis of the seasonal analysis computer program calculated and plotted the cumulative function of monetary returns per hectare. There is little to choose between Treatments 4, 5, and 6 in terms of their cumulative probability function (Fig. 8). Running the 'strategy analysis' option, the mean-Gini dominant treatments of the irrigated experiment were able to be listed, in terms of the costs and prices used to analyze it (Table 3). Actually, the dominant treatments were Treatments 4 and 5- $40 \mathrm{~mm}$ water applied each day ( 2 or $3 d$, respectively) of irrigation.

\subsubsection{Change in crop hybrids and cultivars}

A nother option for adaptation to climate change is the use of later-maturing, but more productive hybrids and cultivars. There is a need for hybrids and cultivars that are more drought resistant, fast grained, and disease and pest tolerant. If these changes could bring only a $10 \%$ increase of the mean grain yield in Bulgaria, it would produce an additional 0.2 million $t$ of maize grain yield and 0.18 million $t$ of wheat grain yield.

The CERES GENERIC 3.0 crop growth models can test the performance of hypothetical new hybrids and cultivars under the conditions of climate change. The development of a hypothetical new cultivar or hybrid with different genetic characteristics would improve winter wheat and maize yield production under the climate change scenarios created. As it is known, one of the genetic inputs entered into the above models is the number of growing degree-days from flowering to maturity. A higher coefficient extends the simulated duration of the grain-filling period under warmer climate conditions. In Table 4, some results obtained under numerical tests of 2 hypothetical new maize hybrids are presented.

Technological innovations, including development of new crop hybrids and cultivars that may be bred to better match the changing climate, are considered a promising adaptation strategy. However, the costs of such innovations, as well as their continued development, are uncertain.

\subsubsection{Change in management practices}

M any practices, such as conservation tilling, furrow diking, terracing, contouring, and planting vegetation to act as windbreaks, will protect fields from water and wind erosion and can help retain moisture by reducing evaporation and increasing water infiltration. Using management practices that reduce dependence on irri- 

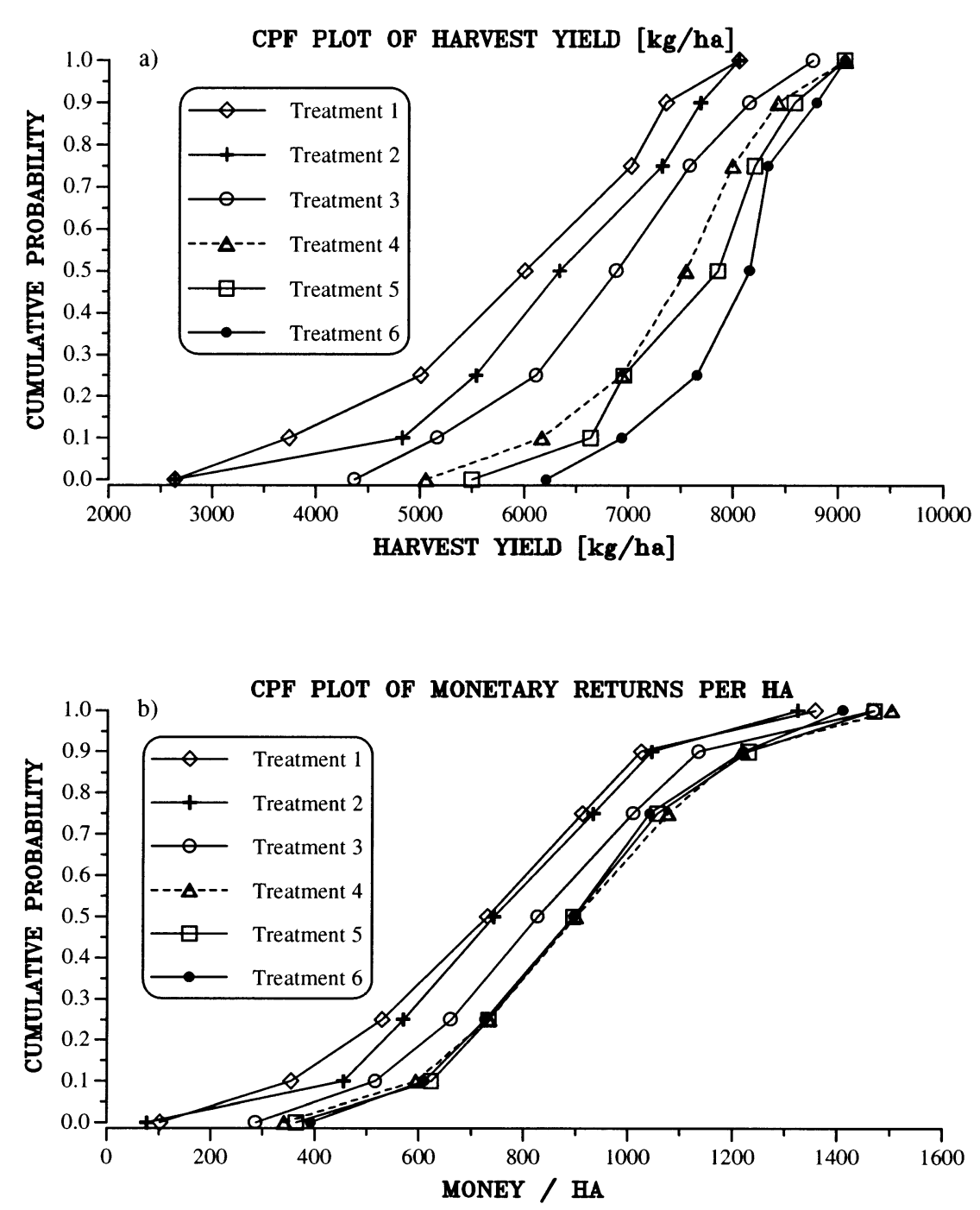

Fig. 8. Cumulative probability function (CPF) plots of the (a) simulated harvest maize yield and (b) monetary returns at Kojnare under the $2 \times \mathrm{CO}_{2} \mathrm{CCC}$ climate change scenario

gation will reduce water consumption without reducing crop yields and will allow greater resiliency in adapting to future climate change.

\subsubsection{Change in management of diseases and pest control}

The warming and increased precipitation expected during the cold half of the year under climate change probably will lead to more occurrences of diseases and pests. The population of granivores in the storehouses is expected to increase on the one hand, and some mushroom diseases and grain shooting will decrease on the other hand. The warm spring will cause an earlier occurrence of the first pest popula- tion. That is why pest control has to be applied earlier relative to the current climate. Generally, in the future climate an increased pest population is expected. Some crop diseases and pests will decrease because of warming and the rainfall deficit during the warm half of the year; however, different kinds of diseases and pests, which currently flourish in the southern regions of the European continent, will appear.

A pplications of fertilizers, pesticides, and weed-control methods are considered to be a necessary adaptive step in Bulgarian agriculture. Depending on the timing of various farming operations and the new crop cycles, this measure could lead to increasing crop yield, though this measure by itself might not have a significant effect. 
Table 3. Strategy analysis determining the dominant numerical treatment examined for Kojnare under the CCC $2 \times \mathrm{CO}_{2}$ climate change scenario. $\mathrm{E}(\mathrm{x})$ : mean return; $\mathrm{G}(\mathrm{x})$ : Gini coefficient

\begin{tabular}{|lccc|}
\hline Treatment & $\begin{array}{c}E(x) \\
(\text { money ha-1 }\end{array}$ & $\begin{array}{c}E(x)-G(x) \\
\left(\text { money ha }^{-1}\right)\end{array}$ & $\begin{array}{c}\text { Efficient } \\
(\text { Yes/No) }\end{array}$ \\
\hline 1 & 714.2 & 548.9 & No \\
2 & 446.0 & 589.3 & No \\
3 & 835.9 & 683.5 & No \\
4 & 905.6 & 756.2 & Yes \\
5 & 904.2 & 759.0 & Yes \\
6 & 896.7 & 757.3 & No \\
\hline
\end{tabular}

\subsubsection{Governmental policy and strategies in the field of agriculture}

Generally, governmental policy and support for research and development will have significant impacts on the agriculture in Bulgaria. The government in this country should support research efforts aimed at vulnerability assessments and agricultural adaptation measures. It is essential to know that, through regional and global cooperation, the government can promote the exchange of advisory services and experiences as well as the transfer of environmental management and rehabilitation technologies that have an impact on agriculture. It is also necessary to remark that government has to utilize the information from research in order to formulate policies concerning climate change and its influence on agriculture. The sustainable growth of agricultural production in Bulgaria should be given one of the highest priorities among all national development programs. Pricing policy can also be used to steer agriculture in a direction more adaptive to climate change. Using pricing policy, the government could make the national agriculture relatively adaptable to climate change.

\subsection{Action plan}

An action plan in Bulgarian agriculture has been developed under the supervision of the M inistry of Agriculture, Forest and Agrarian Reform using the above results (Slavov et al. 1997). The results obtained during the investigation of the climate change impacts in the country force the action plan to be directed to 2 major goals: (1) decrease of greenhouse gas emissions in the atmosphere; and (2) adaptation of agriculture under climate change. To achieve the first goal, the following priority tasks should be executed:

4.3.1. Reducing methane emissions produced by biological fermentation in stock breeding. The most important procedures are expected to be the following: increasing the stock-breeding production by means of improving the genetic characteristics and reproductive abilities of all kinds animals; increasing animal productivity by mechanization of the processes in animal breeding; improving animal feeding and increasing the quality of animal production by reinforced supplements, specific substances, and so forth; improving the organization of meadow and pasture utilization in stock breeding.

4.3.2. Decreasing methane emissions by effective utilization of hard and liquid manure. The relevant steps are expected to be: improving the devices and equipment for gathering and storing hard and liquid manure; constructing and establishing equipment for underground storage of manure, methane extraction, and its utilization; composting manure by using agricultural and industrial waste; improving fertilization using manure (rates, dates of incorporation, machines for transport, and spreading) with different agricultural crops; developing qualitative manure characters and their relevant costs in agriculture.

4.3.3. Improving fertilization using mineral fertilizers. In this case, the main points are projected to be:

Table 4. Departures of phenological stages, grain yield of maize (hybrid group $600)$ and net return using hypothetical new hybrids, relative to the current climate under some $2 \times \mathrm{CO}_{2}$ climate change scenarios at Kojnare. A, B: without/with direct effect of $\mathrm{CO}_{2}$

\begin{tabular}{|lccccc|}
\hline GCM & $\begin{array}{c}\text { New } \\
\text { hybrid }\end{array}$ & $\begin{array}{c}\text { Silking } \\
(\mathrm{d})\end{array}$ & $\begin{array}{c}\text { Full maturity } \\
(\mathrm{d})\end{array}$ & $\begin{array}{c}\text { Grain yield } \\
(\%)\end{array}$ & $\begin{array}{c}\text { Net return } \\
(\%)\end{array}$ \\
\hline UK89 A & 1 & -18 & -35 & -43.7 & -48.1 \\
& 2 & -15 & -26 & -21.2 & -24.8 \\
UK89 B & 1 & -18 & -35 & -36.5 & -44.2 \\
& 2 & -15 & -26 & -18.4 & -21.9 \\
OSU A & 1 & -9 & -21 & -8.4 & -9.4 \\
& 2 & -5 & -11 & +8.1 & +12.1 \\
OSU B & 1 & -9 & -21 & -3.4 & -3.8 \\
& 2 & -5 & -11 & +16.4 & +19.7 \\
HCGG A & 1 & -8 & -20 & -7.2 & -10.8 \\
& 2 & -5 & -10 & +9.9 & +13.2 \\
HCGG B & 1 & -8 & -20 & -4.5 & -7.1 \\
\multirow{2}{*}{ HCGS A } & 2 & -5 & -10 & +10.6 & +15.9 \\
& 1 & -7 & -17 & -6.5 & -8.8 \\
HCGS B & 2 & -4 & -8 & +11.2 & +14.5 \\
& 1 & -7 & -17 & -3.8 & -6.6 \\
& 2 & -4 & -8 & +12.4 & \pm 15.1 \\
\hline
\end{tabular}


incorporation of nitrogen fertilizers, applied in accordance with the soil profiles; incorporation of nitrogen mineral fertilizers, applied together with manure in order to decrease gasses containing nitrogen; incorporation of fertilizers containing nitrogen, immediately tilled and sowed.

4.3.4. Decreasing emissions of carbon-containing gasses and retaining soil carbon. Burning termination of stubble fields and plant remainders; introduction of methods for keeping and improving soil fertility under decreasing carbon dioxide emissions; and application of a system to counter soil water erosion, especially irrigation erosion, should be the major elements of this task.

4.3.5. Decreasing methane emissions in rice cultivation. This objective could be achieved by: rice field construction including an improved system of water drainage; improved rice production technology; and cultivation of new high-productivity rice varieties with improved botanical qualities.

The second part of the action plan includes the following adaptation measures that should be executed under the expected climate change: (1) new zoning of the agroclimatic resources and agricultural crops; (2) introduction of new cultivars and hybrids adapted to climate change; (3) utilization of measures for increasing irrigation effectiveness; and (4) use of adaptation phytosanitary measures.

\section{CONCLUSIONS}

According to the GCM outputs used in the study, annual temperatures in Bulgaria are projected to rise between 2.9 (HCGS) and $5.8^{\circ} \mathrm{C}$ (UK89) under effective doubling of carbon dioxide. Under the GFDL-T transient scenario in the 2030s and 2060s, annual temperatures are projected to increase by 2.2 and $3.9^{\circ} \mathrm{C}$, respectively. In general, precipitation is expected to increase during the winter and to decrease during the warm half of the year. The GCM climate change scenarios were not constructed to help predict the future. They were designed to help identify the sensitivity of sectors (such as agriculture) to climate change. These climate change scenarios can help identify the potential direction of effects and the potential magnitude of impacts.

Atmospheric warming can be expected to lengthen the potential crop growing season, resulting in a shift of the thermal limits of agriculture in Bulgaria. An indication of the extent of this shift is shown by an increase in the accumulated temperature sums for cropping during the growing season above a base of 5 and $10^{\circ} \mathrm{C}$. These relate to changes in the climatic limits for specific crops under a variety of climatic scenarios. Under equilibrium $2 \times \mathrm{CO}_{2}$, the GCM climate change scenarios projected increases in the agroclimatic potential; however, warming caused decreases in grain yield of winter wheat and especially of maize. All yields decreased significantly under the $2 \times \mathrm{CO}_{2}$ scenarios. The GISS maize scenario was more benign than the other scenarios due to precipitation increases. Yield decreases were caused mostly by reduced growing seasons of between $3 \mathrm{wk}$ and a month. When the direct effect of $\mathrm{CO}_{2}$ was assumed in the study, wheat yield increased.

Adaptation measures-such as new zoning of the agroclimatic resources and agricultural crops, introduction of new cultivars and hybrids adapted to climate change, utilization of measures to increase irrigation effectiveness, and use of adaptation phytosanitary measures-were considered as potential responses that may modify any effects of climate change on crop production in Bulgaria.

Major objectives of the action plan supervised by the Ministry of Agriculture, Forest and the Agrarian Reform are decreasing greenhouse gas emissions by reduction of methane emissions produced by biological fermentation in stock breeding and in rice cultivation; decreasing methane emissions by effective utilization of manure; improving fertilization using mineral fertilizers; decreasing the emission of carboncontaining gasses and retaining soil carbon. The action plan was developed according to the rules of United Nations Framework Convention on Climate Change and will be presented in 1999 to the United Nations.

Acknowledgements. The author wishes to thank the US Country Studies Management Team and especially J oel Smith for the opportunity to participate in the US Country Studies Program, information provided, encouragement, and useful suggestions concerning this study. The author also wishes to thank the Bulgarian M inistry of Agriculture, Forest and Agrarian Reform for supervising and providing the action plan in agriculture.

\section{LITERATURE CITED}

Alexandrov $V$ (1993) Long-term variations of rainfall during growing season of some crops in Bulgaria. In: Sevruk B, Lapin M (eds) Proc Int Symp Precip Evap 2:99-104

Alexandrov V (1997a) GCM climate change scenarios for Bulgaria. Bulgarian J Meteorol Hydrol 8(3-4):104-120

Alexandrov $V$ (1997b) A decision support system for agrotechnology transfer (DSSAT) as an approach for irrigation planning and management of maize crop in Bulgaria. In: Refsgaard J, Karalis E (eds) Operational water management. Balkema, Rotterdam, p 237-244

Alexandrov $V$ (1997c) Adaptation of crop-weather models of maize and winter wheat in Bulgaria. Proc 5th Natl Conf Grain, Kostinbrod 4:26-30 (in Bulgarian)

Alexandrov V (1997d) Vulnerability of agronomic systems in Bulgaria. Clim Change 36:135-149 
Alexandrov V (1998) GCM climate change scenarios-warning for Bulgarian agriculture. Proc Natl Conf Disasters, Sofia, p 5-12 (in Bulgarian)

Alexandrov V, Valkov N (1993) A simple stochastic model of climate for calculation of crop productivity. Bulgarian J Meteorol Hydrol 4(3):132-139

Brown RA, Rosenberg NJ (1997) Sensitivity of crop yield and water use to change in a range of climatic factors and $\mathrm{CO}_{2}$ concentrations: a simulation study applying EPIC to the Central USA. Agric For M eteorol 83:171-203

Gulinova N (1974) Methods in agricultural climatology. Gidrometeoizdat, St. Petersburg

Harrison P, Butterfield R, Downing T (eds) (1995) Climate change and agriculture in Europe-assessment of impacts and adaptation. Environmental Change Unit, Oxford

Houghton J , M eira Filho L, Callander B, Harris N, Kattenberg A, Maskell K (eds) (1996) Climate change 1995: the science of climate change. Contribution of Working Group I to the second assessment report of the Intergovernmental Panel on Climate Change. Cambridge University Press, Cambridge

Intergovernmental Panel on Climate Change (IPCC) (1997) The regional impacts of climate change: an assessment of vulnerability. Cambridge University Press, Cambridge

International Benchmark Sites Network for Agrotechnology Transfer (IBSNAT) (1990) Network report 1987-90. University of Hawaii, Honolulu

IBSNAT (1991) Decision support system for agrotechnology transfer (DSSAT) user's guide. University of Hawaii, Honolulu

IBSNAT (1993) The IBSNAT decade. University of Hawaii, Honolulu

Kaiser HM, Drennen TE (eds) (1993) Agricultural dimensions of global climate change. St. Lucie Press, Delray Beach, FL

Koleva E (1993) Trend and variability of precipitation in Bulgaria. In: Sevruk B, Lapin M (eds) Proc Int Symp Precip Evap 2:91-92

Peiris DR, Crawford J W, Grashoff C, J efferies RA, Porter J R, Marshall B (1996) A simulation study of crop growth and development under climate change. Agric For Meteor 79:271-287

Raev I, Slavov N, Grozev O, Alexandrov V, Vasilev Z, Rosnev B, Delkov A (1996) Assessment of forest potential for absorbing greenhouse gases. Vulnerability and adapta- tion assessments of forest and agricultural vegetation in Bulgaria under climate change: mitigation of the influence of climate change in the non-energetic sector. Bulgarian Country Study to address climate change inventory of the greenhouse gases emission sources and sinks alternative energy balance and technical programs. Energoproekt, Sofia, p 22-40 (in Bulgarian)

Republic of Bulgaria (RB) (1996) Chap 6. Vulnerability to climate change and adaptive strategies. The first national communication on climate change. Energoproekt, Sofia

Rosenzweig C, Hill D (1995) Potential impacts of climate change on agriculture and forest supply. Consequences 1(2):22-32

Rosenzweig C, Parry M (1994) Potential impacts of climate change on world food supply. Nature 367:133-138

Rosenzweig C, Allen L, Harper L, Hollinger S, J ones J (eds) (1995) Climate change and agriculture: analysis of potential international impacts. A merican Society of Agronomy, Madison, WI, no. 59

Slavov N, Alexandrov V (1997) Influence of global climate change on agroclimatic resources in Bulgaria. Comp Rend Acad Bulgare Sci 50(2):31-34

Slavov N, Georgiev G, Alexandrov V (1996) Agrometeorological methods for assessment of maize and winter wheat growth in Bulgaria. Bulgarian J Agric Sci 2(2):37-48

Slavov N, Ivanova E, Rousev N, Slavov D, Houmbadjieva N (1997) Action plan in agriculture under climate change in Bulgaria. Bulgaria Climate Change Country Study. Support for national climate change action plan for Bulgaria. Energoproekt, Sofia, p 14-16

Smith J, Bhatti N, Menzhulin G, Benioff R, Budyko M, Campos M, J allow B, Rijsberman F (eds) (1996) Adapting to climate change. Springer, New York

Tsuji G, Uehara G, Balas S (eds) (1994) DSSAT version 3, Vols 1-3. IBSNAT. University of Hawaii, Honolulu

Watson R, Zinyowere M, M oss R (eds) (1996) Climate change 1995-impacts, adaptation and mitigation of climate change. Contribution of Working Group II to the second assessment report of the IPCC. Cambidge University Press, Cambridge

Wei Y, Hoogenboom G, McClendon R, Gresham DD (1994) Impact of climate change on crop production at a farm level. ASAE paper no. 943523. American Society of Agricultural Engineers, J oseph, $\mathrm{MI}$ 